\title{
Leptomeningeal Carcinomatosis Originated from Breast Cancer
}

\author{
Seniha Şenbayrak1, Seyfi Çelik Özyürek1, Orçun Barkay¹, Çiğdem Akalan Kuyumcu¹, Fügen Aker² \\ ${ }^{1}$ Department of Infectious Diseases and Clinical Microbiology, Haydarpasa Numune Education and Research Hospital, \\ Istanbul, Turkey \\ ${ }^{2}$ Department of Pathology, Haydarpasa Numune Education and Research Hospital, Istanbul, Turkey
}

\begin{abstract}
Malignant melanoma, breast cancer and lung cancer are the most causative malignancies of leptomeningeal carsinomatosis (LC). A LC case that was previously diagnosed as tuberculosis meningitis, is presented here to emphasize the importance of maintaining a broad differential diagnosis in patients applied to the hospital with meningeal irritation symptoms. A 35-year-old woman was suffering from a severe headache and photophobia. Physical examination revealed nuchal rigidity but Kernig's and Brudzinski signs were negative. Cerebrospinal fluid (CSF) findings were 171 cells/mm3 (lymphocytic predominance), elevated protein levels, decreased glucose. Atypical cells were detected in CSF cytology. The result of breast biopsy was in accordance with breast lobular carcinoma nuclear grade III. LC, usually developes in patients who have a known primary malignancy. As it occured in our case; in up to $10 \%-20 \%$ of cases, however, symptoms caused by LC may emerge before the diagnosis of the primary tumor. It should remember that meningitis may not be always infectious originated. J Microbiol Infect Dis 2015;5(3): 133-136
\end{abstract}

Key words: leptomeningeal carcinomatosis, meningitis, cerebrospinal fluid cytology

\section{Meme kanseri kaynaklı leptomeningeal karsinomatozis}

\section{ÖZET}

Meme kanseri, akciğer kanseri ve malign melanom leptomeningeal karsinomatosize (LK) neden olan en sık malignitelerdir. Meningeal iritasyon bulguları olan hastalarda geniş ayırıcı tanı yapılmasının önemini vurgulamak için, tüberküloz menenjit ön tanısı almış bir LK olgusu sunulmuştur. Ciddi başağrısı ve fotofobi yakınması olan otuz beş yaşında kadın hastanın fizik muayenesinde ense sertliği vardı fakat Kernig-Brudzinsky belirtisi negatifti. Serebrospinal sıvı (BOS) analizinde, 171 hücre/mm3(lenfosit baskın) artmış protein seviyesi, azalmış glukoz saptandı. BOS sitolojisinde atipik hücreler görüldü. Meme biyopsisinin sonucu nükleer grade 3 meme lobüler karsinomu ile uyumluydu. LK, genellikle bilinen primer malignitesi olan hastalarda rastlanır. Bizim vakamızda olduğu gibi, vakaların \% 10-20'sinde primer tümörün tanısı konulmadan önce LK'e sekonder gelişen semptomlar ortaya çıkabilir. Menenjitin her zaman enfeksiyöz orjinli olmayabileceği unutulmamalıdır.

Anahtar kelimeler: leptomeningeal karsinomatozis, menenjit, serebrospinal sıvı sitolojisi

\section{INTRODUCTION}

Central nervous system (CNS) could be infected by various agents including viruses, bacteria, fungi, protozoa and helminths. In addition, diverse noninfectious etiologies may resemble CNS infections. These include neoplastic diseases, intracranial tumors and cysts, medications, collagen vascular disorders and other systemic illnesses. ${ }^{1}$ Patients with breast and lung cancer and malignant melanoma are most likely to develope leptomeningeal carcinomatosis (LC). ${ }^{2-4}$ Traditionally, the combination of clinical symptomatology and demonstration of malignant cells in cerebrospinal fluid (CSF) have been required to establish a diagnosis of LC. ${ }^{5}$ Contrast enhanced magnetic resonance imaging (MRI) has emerged as a reliable diagnostic tool in LC. ${ }^{5,6}$ Overall survival of breast cancer associated with LC remains less than 6 months on average with current treatments. A case of LC which is relatively a rare clinical entity, previously identified as tuberculosis meningitis, is presented here. 


\section{CASE}

A 35 year-old, female patient with severe headache, nausea and vomitting symptoms had been admitted to a private hospital. Examination had revealed signs of meningeal irritation. MRI had defined dif- fuse meningeal involvement (Figure 1 and Figure 2). CSF findings had included an elevated cell count, a mildly elevated protein and a markedly depressed glucose. The patient was sent to our department with a preliminary diagnosis of tuberculosis meningitis.

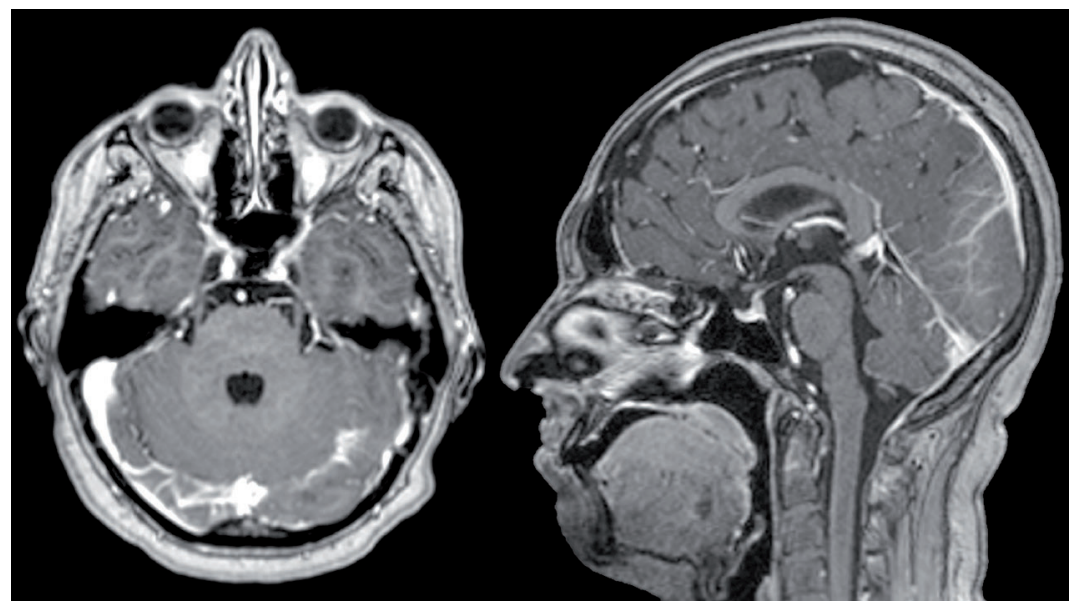

Figure 1. Postgadolinium T1weighted magnetic resonance image. Leptomeningial involvement signs which was characterized with common subarachnoidal intensity increase at precontrast flair images and common pial subarachnoidal signal intensity changes at postcontrast images were seen.

She was suffering from a severe headache localized to fronto-occipital area and photophobia. She was afebrile, hemodinamically stable. And is going to be removed. New sentence is going to be: The physical examination. Kernig's and Brudzinski's signs were negative. Chest radiography was normal. A lumbar puncture (LP) was performed afterwards, an analysis of the CSF revealed 171 cells/ $\mathrm{mm}^{3}$ (lymphocytic predominance), $12 \mathrm{mg} / \mathrm{dl}$ glucose (corresponding serum glucose $100 \mathrm{mg} / \mathrm{dl}$ ), $41 \mathrm{mg} /$ dl protein. Wright agglutination, rapid plasma reagin and Treponema pallidum hemagglutination assay were negative at serum.

During the clinical observation, her headache complaint got worse and diplopia occured. CSF cytology evaluation: Atypical cells with large, hyperchromatic nucleus including selectable nucleolus in a narrow cytoplasm was seen at hypocellular smears (Picture 1). During the patient's physical examination, a mass was detected in the right breast and multipl lymphadenopathies in right axillary were found. An ultrasound-guided biopsy confirmed the diagnosis of breast cancer. Pathologic result was in accordance with breast lobuler carcinoma nuclear grade III (Picture 2). Bacterial culture, culture of viruses, criptococcal antigen testing, stains of mycobacterium and fungi, polymerase chain reaction assay for mycobacterium tuberculosis were all negative.

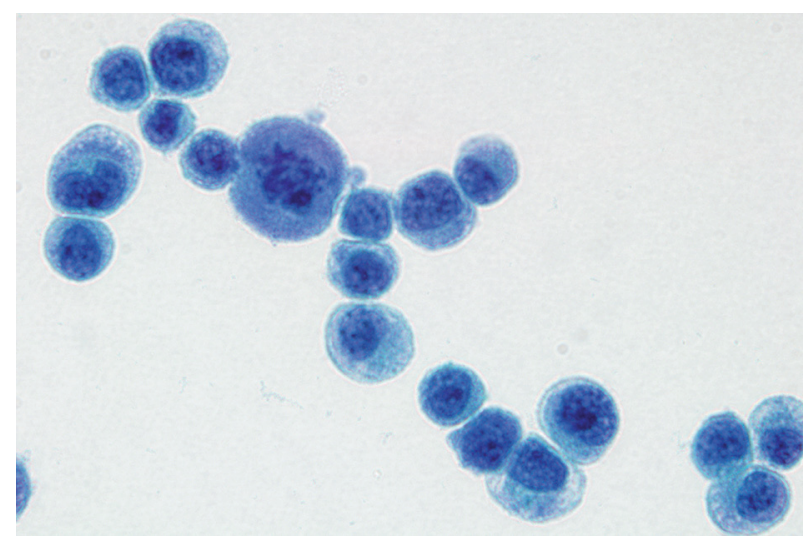

Picture 1. CSF cytology: Atypical/pleomorphic cells with large, hyperchromatic nucleus including macro nucleolus in a narrow cytoplasm at Thin-Prep material of CSF such as the tumour cells of breast (PAP X 100).

Based on the symptoms and the findings, coherent neuroimaging, CSF cytology and breast biopsy results; the patient was diagnosed as LC originated of breast cancer. Her clinical condition worsened over the course of her hospital stay. She was referred to an oncology center. 


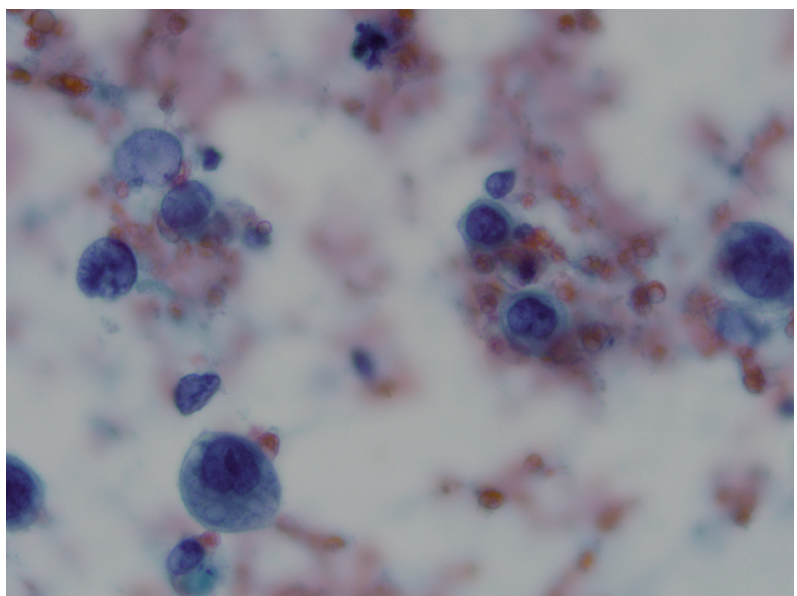

Picture 2. Breast cytopathology: Non-grouped severely atypical/pleomorphic tumor cells scattered as one by one on necrotic background at fine needle aspiration biopsy material of breast (PAP X 100).

\section{DISCUSSION}

LC, occurs as a result of the malignant leptomeningeal (the arachnoid membrane and the pia mater) infiltration and it is not a common finding of tumors. ${ }^{2-4,7}$ This situation, synonymous with carsinomatous meningitis and meningeal carcinomatosis terms. ${ }^{3,4}$ It was observed that it occurred in \%3-\%8 of solid tumors. ${ }^{4,7}$ The most common tumors causing LC are breast cancer, lung cancer and malignant melanoma. ${ }^{2,5,6}$ As LC can be seen generally in patients with known solid tumors, meningitis symptoms can occur before the diagnosis of primary solid tumor in up to $10 \%-20 \%$ of the cases. ${ }^{8} \mathrm{Ma}-$ lignant invasion of the leptomeninges occurs most commonly by either hematogenous dissemination or direct extension from primary systemic or central nervous system tumours. ${ }^{9,10}$

Patients mostly seem like meningitis with clinical symptoms (often being a combination of cranial nerve, cerebral, and spinal signs and symptoms on admission) and CSF findings. ${ }^{8}$ The most common symptoms are headache, change in mental status, nausea, vomitting, limb weakness, sensory disturbances, diplopia, dysphagia, dysarthria, coordination disorders. ${ }^{2-5,9,11}$ Neck stiffness is seen at 7\%$17 \%$ of the cases. ${ }^{2-5,9,11}$ Fever is characteristically absent.

The CSF is nearly abnormal in all cases. . $^{9,10,12}$ At least $50 \%$ of cases shows an elevated opening pressure, $30 \%-50 \%$ a decrease in the glucose concentration, $70 \%-90 \%$ an elevation in the protein concentration. An elevation in the white cell count (lymphocytic predominance, usually less than 100 cells $/ \mathrm{mm}^{3}$ ) is also seen. ${ }^{3,11}$ The criteria for the diagnosis of LC is based mainly on examination of CSF.

LC can be diagnosed $50 \%-70 \%$ by cytology at the first LP. ${ }^{4-6}$ With three punctures, this ratio gets over $90 \%$. CSF cytology can be negative at $10 \%$ of the cases. ${ }^{2-5,10}$ Positive CSF cytology is rarely the presenting sign of CNS metastasis; most patients have a known history of malignancy. Therefore, it is usually possible and always desirable to compare the morphology of the metastasis with that of the primary lesion. In those unusual cases in which positive CSF cytology is the initial manifestation of cancer, consider carcinomas of lung and stomach or melanoma, because the primary tumor can be small and occult, and can metastasize early. Although breast carcinoma is one of the most common tumor types to involve the CNS, it only rarely presents as an unknown primary tumor in the CSF. Leptomeningeal spread is particularly likely with lobular carcinoma of the breast. ${ }^{10}$ CSF vascular endothelial growth factor (VEGF) has $75 \%$ sensitivity, $97 \%$ specifity, and $94 \%$ negative predictive value in the diagnosis of breast cancer LC using CSF cytology as a gold standard. ${ }^{5}$ The reported sensitivity for contrast enhanced MRI is $60 \%-75 \%$ for LC. ${ }^{13}$

In our patient, diagnosis was made by the first lomber puncture. ${ }^{4,5,12}$ CSF cytology showed malignant cells. ${ }^{2-5,10}$ When the primary solid tumour was investigated, a mass at the right breast was found. Breast biopsy performed and showed that the LC is originated from breast. In up to $10 \%-20 \%$ of cases, however, symptoms caused by LC may emerge before the diagnosis of the primary tumour as with our patient. Radiation therapy and intrathecal chemotherapy are the options for treatment of LC. However, the overall prognosis is still poor. Survival time without a treatment is about 6 weeks, and the average survival time with a treatment is about 3 to 6 months. ${ }^{13}$ It is concluded that cytological evaluation of CSF is very important in all patients with signs of menengitis.

\section{Ethics Committee Approval: N/A.}

Informed Consent: Written informed consent was obtained from the patient who participated in this study.

Competing interest: The authors declare that they have no competing interests.

Sources of funding: None 


\section{REFERENCES}

1. Tunkel AR, Beek DV, Scheld WM. Acute Meningitis. In: Mandell GL, Bennett JE, Dolin R, eds. Mandell, Douglas, and Bennett's Principles and Practice of Infectious Diseases, $7^{\text {th }}$ ed. Philadelphia, PA: Churchill Livingstone Elsevier 2009; 1189-1229

2. Gripshover BM, Ellner JJ. Chronic meningitis syndrome and meningitis of noninfective or uncertain etiology. In: Scheld WM, Whitley RJ, Durack DT, eds. Infectious of The Central Nervous System, $2^{\text {nd }}$ ed. Philadelphia, PA: Lippincott-Raven Publishers 1997; 881-896.

3. Pavlidis N. The diagnostic and therapeutic management of leptomeningeal carcinomatosis. Ann Oncol 2004;15:285-291.

4. Zachariah B, Zachariah SB, Varghese R, Balducci L. Carcinomatous meningitis: clinical manifestations and management. Int J Clin Pharmacol Ther 1995; 33:7-12.

5. Scott BJ, Kesari S. Leptomeningeal metastases in breast cancer. Am J Cancer Res 2013; 3:117-126.

6. Walkty A, Abbott B, Swirsky N, Safneck J, Embil JM. Keeping an open mind about meningitis: a case report of carcinomatous meningitis. CJEM 2011; 13:352-356.
7. Taillibert S, Laigle-Donadey F, Chodkiewicz C, Sanson M, Hoang-Xuan K, Delattre JY. Leptomeningeal metastases from solid malignancy: a review. J Neurooncol 2005; 75:85-99.

8. Hildebrand J, Aoun M. Chronic meningitis: still a diagnosticchallenge. J Neurol 2003; 250:653-660.

9. Grossman SA, Krabak MJ. Leptomeningeal carcinomatosis. Cancer Treat Rev 1999; 25:103-119.

10. DeMay RM. Cerebrospinal fluid. In: DeMay RM, Ed. The Art \& Science Of Cytopathology, 2nd ed. Chicago, PA: ASCP 2012;490-534.

11. Balm M, Hammack J. Leptomeningeal carcinomatosis: presenting features and prognostic factors. Arch Neurol 1996;53:626-632.

12. Glantz MJ, Cole BF, Glantz LK, et al. Cerebrospinal fluid cytology in patients with cancer: minimizing false-negative results. Cancer 1998; 82:733-739.

13. McNally ME, Carson W.Occult breast cancer presenting as leptomeningal carcinomatosis. World J Oncol 2012; 3:73-77. 